\title{
PENINGKATAN KUALITAS PEMBELAJARAN DENGAN IMPLEMENTASI LESSON STUDY PADA MATA PELAJARAN IPA DAN IPS DI SMPIT GENERASI RABBANI KOTA BENGKULU
}

\author{
Haifa Wahyu $^{\text {a }}$, Herlenayatib, Medi Prasetiac ${ }^{\mathrm{c}}$, Liza Fitri Lina ${ }^{d}$ \\ ${ }^{\mathrm{a}, \mathrm{d}}$ Keperawatan, Universitas Muhammadiyah Bengkulu, Indonesia \\ ${ }^{\mathrm{b}}$ SMPN 5 Kota Bengkulu, Indonesia \\ ${ }^{\mathrm{c}}$ SMPIT Generasi Rabbani Kota Bengkulu, Indonesia
}

\begin{abstract}
ABSTRAK
Kebutuhan akan orientasi baru dalam pendidikan terasa begitu kuat dan nyata dalam berbagai aspek dan bidang kajian, baik eksakta maupun ilmu-ilmu sosial. Para pendidik dan praktisi pendidikan sudah seharusnya mampu merespon perubahan yang terjadi dengan mengubah paradigma pendidikan. Salah satu cara untuk menjawab dan mengatasi perubahan yang terjadi secara terus-menerus adalah dengan mengimplementasikan berbagai model pembelajaran inovatif, yang diharapkan mampu mendongkrak kualitas proses pembelajaran. Lesson Study merupakan suatu cara untuk meningkatkan profesionalisme pendidik melalui pendekatan kolaboratif. Dalam metode ini termuat prinsip kolaborasi saling membantu untuk membangun komunitas belajar. Lesson Study memiliki tiga siklus kajian, yaitu plan (merencanakan), do (melaksanakan), dan see (merefleksi). Ketiga siklus kajian tersebut, yaitu (1) plan; secara kolaboratif guru model merencanakan pembelajaran berpusat pada siswa, (2) do; seorang guru model melaksanakan pembelajaran yang berpusat pada siswa, dan guru lain mengobservasi aktivitas belajar siswa, dan (3) see; melalui prinsip kolaboratif merefleksikan keefektifan pembelajaran. Pelaksanaan kegiatan pengabdian masyarakat ini berlangsung pada tanggal 24-28 Februari 2020 di SMPIT Generasi Rabbani Kota Bengkulu. Hasil Pelaksanaan Pengabdian Masyarakat ini didapatkan peningkatan kualitas pembelajaran pada mata pelajaran IPA dan IPS yang tampak dari antusiasme para siswa memperhatikan pembelajaran, sebagian besar siswa dapat memahami materi dan tujuan pembelajaran dapat tercapai dilihat dari mengerjakan LKS, hasil presentasi siswa dan siswa lebih banyak yang aktif dari pembelajaran biasanya. Rencana tindak lanjut sebagai saran kepada pihak sekolah yaitu melaksanakan lesson study secara rutin pada mata pelajaran IPA dan IPS.
\end{abstract}

Kata kunci: Kualitas Pembelajaran, Lesson Study, Pelajaran IPA dan IPS 


\section{Pendahuluan}

Pendidikan merupakan aspek penting dalam peningkatan kualitas kehidupan manusia. Bahkan kualitas hidup dan perilaku individu, sosial masyarakat atau bangsa sangat tergantung pada proses penyelenggaraan pendidikan itu sendiri, termasuk orientasi, landasan filsofis, kurikulum, metode, pendekatan maupun lingkungan pendidikan. melalui pendidikan bermutu, bangsa dan negara akan terjunjung tinggi martabatnya di mata dunia. Maka diperlukan model pembelajaran yang tidak hanya mampu menjadikan peserta didik cerdas dalam teoritical science (teori ilmu) tetapi juga cerdas dalam practical science (praktik ilmu). Oleh karena itu diperlukan strategi bagaimana pendidikan bisa menjadi sarana untuk membuka pola pikir peserta didik bahwa ilmu yang mereka pelajari memiliki kebermaknaan untuk hidup. Sehingga ilmu tersebut mampu mengubah sikap, pengetahuan, dan keterampilan menjadi lebih baik. (Aris Shoimin, 2014)

Diakui atau tidak pada zaman yang modern ini, sebagian besar guru mengajar menggunakan metodelogi tradisional. Cara mengajar tersebut bersifat otoriter dan berpusat pada guru (teacher centered). Kegiatan pembelajaran berpusat pada guru sedangkan siswa hanya dijadikan objek bukan sebagai subjek. Metodologi tradisional menjadikan siswa tidak bebas untuk mengemukakan pendapatnya. Sehingga siswa sulit mengembangkan potensi-potensi yang ada pada dirinya (Aris Shoimin, 2014). Contoh Permasalahan yang sering dihadapi dalam proses pembelajaran yaitu guru melakukan kegiatan pembelajaran hanya menggunakan satu metode saja seperti ceramah sehingga proses pembelajaran terpusat pada guru dan siswa menjadi pasif. Ada pula pembelajaran yang tidak sesuai dengan rencana proses pembelajaran (RPP). Misalnya guru hanya memberikan tugas dan guru hanya dudukduduk di kelas atau kelas ditinggal oleh guru begitu saja tanpa ada guru jaga lainnya. (Rusman, 2011)

Tidak hanya mendidik dan mengajar, seorang pendidik juga harus memperhatikan proses pembelajaran dan hasil pembelajaran serta administrasi pembelajaran seperti halnya Rencana Proses Pembelajaran (RPP). Maka seorang guru harus bisa mengelola pembelajaran yang efektif dan efisien.

Menurut Yan Vita pembelajaran yang tepat sasaran (efektif) adalah pembelajaran yang mendidik, yang secara serentak dapat mencapai dua sisi penting dari tujuan pendidikan di sekolah yakni, memiliki atau menguasai ilmu pengetahuan teknologi dan seni (IPTKS), membangun diri pribadi sebagai pemanggung eksistensi manuasia.

\section{Ada beberapa komponen} pembelajaran yaitu, guru, sarana prasarana, metode dan srategi pembelajaran, serta pembelajaran yang menyenangkan. Komponen yang mempengaruhi pendidikan dan pengajaran tersebut disiapkan dan didesain dengan baik, maka mutu pendidikan dengan sendirinya meningkat. Namun dari seluruh komponen tersebut, gurulah yang merupakan komponen utama. Jika kualitas guru baik berkualitas baik, maka pendidikan akan baik pula karena di tangan guru yang baik keterbatasan apapun 
dapat diatasi atau diminimalkan. (Moh.

Roqib dan Nurfuandi, 2008)

Sesuai PP Nomor 19 Tahun 2005

tentang Standar Nasional Pendidikan merupakan usaha pemerintah untuk meningkatkan mutu pendidikan di Indonesia. Pasal 19 dari PP tersebut menjelaskan bahwa "Proses pembelajaran pada satuan pendidikan dilaksanakan secara interaktif, inspiratif, menyenanangkan, menantang, memotivasai peserta didik berprestasi aktif, serta memberikan ruang yang cukup bagi prakarsa, kreativitas dan kemandirian sesuai bakat, minat dan perkembangan fisik serta psikologis peserta didik". Dalam PP tersebut menjelaskan bahwa sekarang pemerintah menaruh perhatian terhadap mutu proses pendidikan dalam proses pembelajaran. Agar pendidikan di Indonesia lebih berkembang. Untuk meningkatkan proses pembelajaran upaya yang demikian disebut dengan istilah Lesson study.

Menurut Rusman (2011) lesson study merupakan alternatif untuk mengatasi masalah praktek pembelajaran yang selama ini dipandang kurang efektif. Permasalahanpermasalahan yang berhubungan dengan mutu pendidikan di Indonesia dan usahausaha yang dilakukan pemerintah dalam rangka meningkatkan mutu pendidikan terus menerus dilakukan. Kegiatan pembelajaran di Indonesia umumnya dilakukan dalam bentuk ceramah satu arah. Guru lebih banyak menyuapi siswa, sementara siswa hanya mendengarkan. Sehingga guru tidak memberikan kesempatan kepada siswa untuk berinspirasi dan tidak melatih untuk hidup mandiri serta kurang memberikan motivasi pada siswa. Kegiatan Lesson Study juga salah satu metode yang diyakini dapat mendukung tumbuhnya kompetensi guru, selain melalui pendidikan profesi.

Lesson study merupakan kegiatan kolaboratif yang dilakukan oleh sekelompok guru dalam rangka meningkatkan kinerja dan kualitas pembelajaran mereka yang pada ujungnya dapat meningkatkan kompetensi dan profesionalisme guru. Ada beberapa tahap dalam lesson study yaitu plan (perencanaan), do (pelaksanaan), see (refleksi), act (tindak lanjut). Lesson study memberikan banyak kesempatan kepada guru untuk membuat bermakna ide-ide pendidikan dalam praktik pembelajaran mereka, untuk mengubah perspektif mereka tentang pembelajaran, dan untuk belajar mengamati praktik pembelajaran mereka dari perspektif siswa. Melalui lesson study, guru dapat secara objektif melihat apa yang terjadi dalam praktik pembelajaran.

Menurut Aris Shoimin (2014) Berhasil atau tidaknya pendidikan tergantung apa yang diberikan dan diajarkan oleh guru. Hasil-hasil pengajaran dan pembelajaran berbagai bidang disiplin ilmu terbukti selalu kurang memuaskan berbagai pihak yang berkepentingan (stakeholder). Untuk memperbaiki dan meningkatkan mutu proses dan hasil pembelajaran Upaya untuk menuju keprofesionalan guru dengan lesson study merupakan hal yang baik dan bagus untuk diterapkan pada setiap lembaga sekolah ataupun setiap yayasan untuk memajukan mutu SDM (sumber daya manusia). Secara tidak langsung, kegiatan ini meningkatkan kompetensi kepribadian dan kompetensi sosial anggota tim. 
Sedangkan aktivitas guru dalam mengidentifikasi berbagai masalah dalam praktik pembelajaran, mencari sosial, merencanakan pembelajaran secara langsung maupun tidak langsung akan meningkatkan kompetensi pedagogik dan kompetensi profesional guru. Maka kegiatan lesson study yang dirancang dengan baik berpotensi sebagai sarana untuk mengembangkan kompetensi guru dalam menunjang tugas profesionalisme guru.

Aktivitas pembelajaran dapat ditunjukkan melalui pembelajaran yang berpusat pada siswa. Hal ini sesuai dengan pendapat Daryanto dan Muljo (2012), dalam proses pembelajaran, guru dapat menggali dan mengembangkan aktivitas pembelajaran yang berpusat pada siswa. Menurut Abdul Gafur (2012), aktivitas siswa meliputi aktivitas mental (memikirkan jawaban, merenungkan, membayangkan, merasakan) dan aktivitas fisik (melakukan latihan, menjawab pertanyaan, merangsang, menulis, mengerjakan tugas, dsb). Pada proses pembelajaran siswa harus aktif belajar dan guru hanya membimbing dan mengarahkan. Pendekatan pembelajaran yang mampu melibatkan siswa secara langsung akan menghasilkan pembelajaran yang lebih efektif sehingga dapat mencapai tujuan pembelajaran (Daryanto dan Muljo, 2012: 33). Jadi, proses pembelajaran bukan hanya sekedar menghafal sejumlah konsep, prinsip atau fakta, tetapi siswa mampu memahami manfaat dari mempelajari suatu materi dengan cara melibatkan mereka untuk aktif terlibat langsung dalam pembelajaran sehingga tujuan pembelajaran dapat tercapai.
Pembelajaran IPA dan IPS bukan hanya untuk mentransfer konsep saja namun lebih pada pencapaian tujuan IPA dan IPS. karena dalam pembelajaran IPA dan IPS siswa diharapkan memperoleh pemahaman terhadap sejumlah konsep kemudian mengembangkan serta melatih sikap, nilai, moral, dan keterampilannya berdasarkan konsep yang telah dimilikinya (Etin Solehatin dan Raharjo, 2007: 14). Penekanan pembelajaran IPA dan IPS terletak pada apa yang dipelajari siswa dapat menjadi bekal dalam memahami kehidupan masyarakat dan lingkungannya.

Pada kurikulum 2013, pembelajaran IPA dan IPS di SMP disajikan dengan cara terpadu. Makna terpadu dalam pembelajaran IPA dan IPS adalah keterkaitan antardimensi kehidupan (alam, sosial, ekonomi, budaya, politik, sejarah) yang tertuang dalam Standar Isi (Standar Kompetensi dan Kompetensi Dasar) IPA dan IPS, sehingga melahirkan konsep, tema atau topik pembelajaran (Supardi, 2011). Standar Kompetensi dan Kompetensi Dasar IPA dan IPS terangkum dalam tema atau topik tertentu yang berasal dari disiplin ilmu biologi, fisika untuk IPA dan geografi, ekonomi, sejarah, dan sosiologi untuk IPS.

Dukungan menjadi kebutuhan guru saat melaksanakan lesson study. Berkonsultasi dengan teman adalah hal yang penting. Saling membantu sangat bermanfaat bagi pengembangan profesi guru. Pada tahap perencanaan para peserta harus saling aktif memberikan dukungan. Dukungan teknis dari pihak luar, seperti dosen universitas dan pengawas sangat diterima oleh guru sebagai pendukung 
pengetahuan mereka terhadap materi atau keterampilan dalam merancang pembelajaran.

Berdasarkan berbagai hal yang telah diuraikan, maka pengabdian masyarakat dengan judul "Peningkatan Kualitas Pembelajaran dengan Implementasi Lesson Study pada Mata Pelajaran IPA dan IPS di SMPIT Generasi Rabbani Kota Bengkulu" perlu dilakukan.

\section{Metode}

Pengabdian masyarakat ini dilakukan di Sekolah Menengah Pertama Islam Terpadu (SMPIT) Generasi Rabbani, Kota Bengkulu. Provinsi Bengkulu. Pelaksanaan kegiatan pengabdian kepada masyarakat ini dilakukan selama lima hari, yaitu tanggal 24-28 Februari 2020. Kegiatan ini dihadiri oleh 2 orang guru model (IPA dan IPS), 4 guru Observer, 3 orang pelaksana pengabdian masyarakat, dan seluruh siswa kelas 7B dan 8B . Kegiatan ini dilakukan dengan kisaran 80-120 menit. lesson study dibagi menjadi tiga bagian yaitu plan (perencanaan), do (pelaksanaan dan observasi), dan see (refleksi).

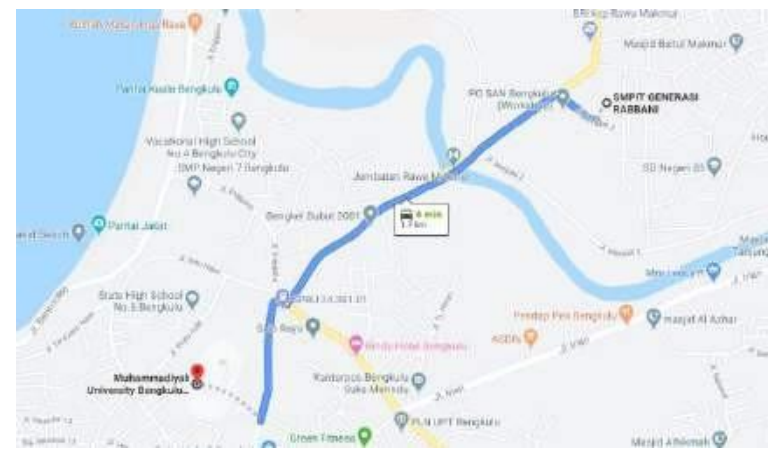

Gambar 1: Lokasi SMPIT Generasi Rabbani dan Universitas Muhammadiyah Bengkulu
Kegiatan plan lesson study IPA dan IPS merupakan kegiatan awal yang dilakukan untuk melaksanakan kegiatan lesson study dalam pembelajaran IPA dan IPS di sekolah menengah pertama islam terpadu Generasi Rabbani. Kegiatan ini mencakup persiapan open lesson dan perencanaan pembelajaran IPA dan IPS.

Kegiatan do lesson study IPA dan IPS merupakan kegiatan untuk melaksanakan yang dipersiapkan dalam open lesson IPA dan IPS dan melaksanakan pembelajaran IPA dan IPS yang telah direncanakan oleh guru IPA dan IPS. Kegiatan ini meliputi guru melaksanakan pembelajaran IPA dan IPS, pengamat mengamati pembelajaran IPA dan IPS, dan kualitas siswa dalam pembelajaran IPA dan IPS.

Kegiatan see lesson study IPA dan IPS merupakan kegiatan terakhir dalam pelaksanaan lesson study. Beberapa komponen yang harus diamati dalam kegiatan ini yaitu proses berlangsungnya kegiatan refleksi, manfaat, kendala, dan solusi kegiatan lesson study IPA dan IPS.

\section{Hasil dan Pembahasan}

Tahapan lesson study dimulai dari tahap perencanaan (plan). perencanaan tidak dilakukan sendirian oleh pendidik, tetapi dilakukan secara bersama dengan berkolaborasi. Beberapa guru berkolaborasi bersama tim pengabdi untuk memperkaya ide dan menyusun rencana pembelajaran bersama-sama. Beberapa guru tersebut merencanakan pembelajaran dan menentukan materi dan media yang direncanakan, bagaimana merencanakan, 
siapa yang merencanakan, pemilihan guru model, persiapan untuk Open Lesson, dan kebutuhan akan dukungan teknis. Pada Tahap perencanaan ini, terpilihlah Bapak Rozi Aprilian, S.Pd sebagai Guru Model untuk Mata Pelajaran IPS, dan Ibu Anik Astuti, S.Pd sebagai guru model untuk mata Pelajaran IPA.

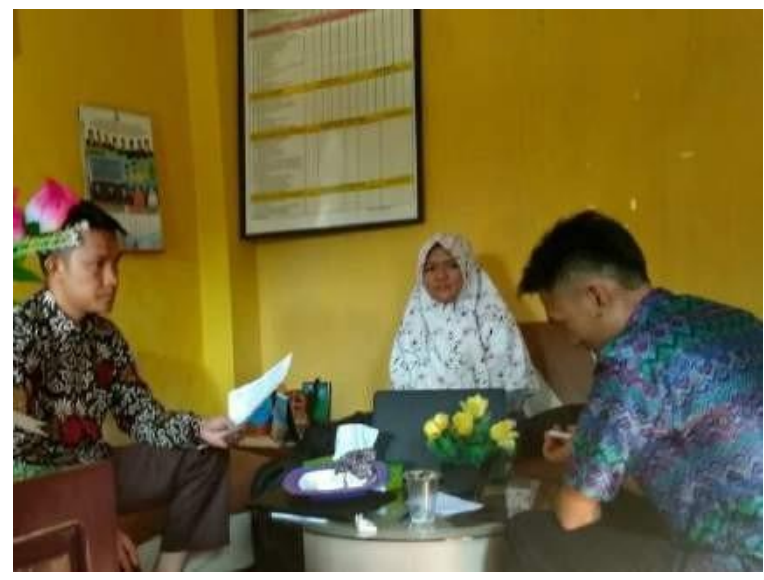

Gambar 2: Pelaksanaan Plan (Perencanaan Lesson Study IPS)

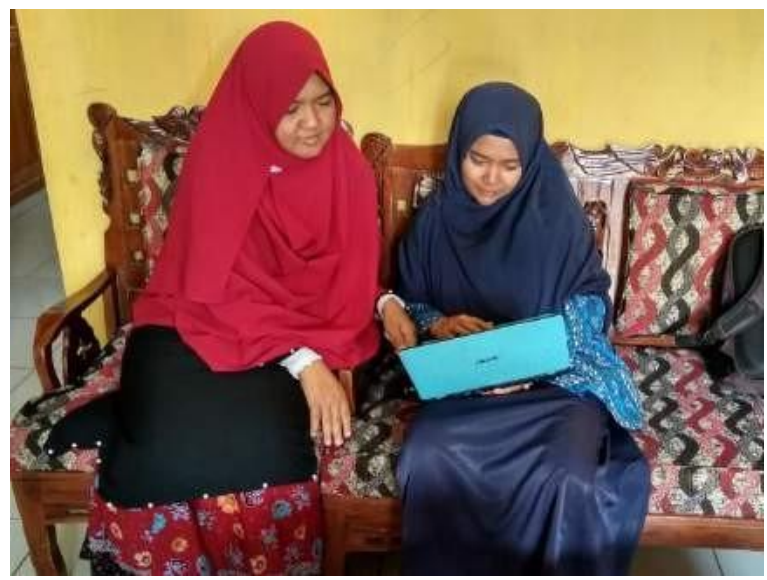

Gambar 3: Pelaksanaan Plan (Perencanaan Lesson Study IPA)

Menurut Nurbaity, Sondang, dan Wahyu (2010), tahap plan yaitu merencanakan proses pembelajaran (RPP) dapat dimulai dengan diskusi tentang permasalahan di kelas, seperti yang berhubungan dengan materi ajar, strategi pembelajaran, evaluasi dan instrument LKS. Pada RPP kita harus menentukan materi, tujuan pembelajaran, metode dan alat yang digunakan dalam pembelajaran. Siswa sebaiknya diberikan kesempatan untuk saling berdiskusi demi pemahaman suatu materi sehingga tujuan pembelajaran dapat tercapai. Ketercapaian tujuan pembelajaran juga dapat dilihat melalui hasil siswa dalam mengerjakan LKS. Oleh karena itu, guru harus memikirkan secara mendalam mengenai apa yang perlu diberikan dalam LKS guna merangsang penalaran siswa.

Pada Tahap ini, Bapak Rozi Aprilian S.Pd berencana menggunakan metode pemutaran video yang dilanjutkan dengan diskusi kelompok untuk Mata Pelajaran IPS, sedangkan Ibu Anik Astuti, S.Pd menggunakan metode presentasi kelompok yang dilanjutkan dengan tanya jawab antar kelompok siswa untuk mata pelajaran IPA.

Guru model menjelaskan (1) apa yang harus mereka ketahui; (2) tugas-tugas apakah yang harus digunakan untuk memancing minat siswa dan tetap membuka kesempatan bagi para siswa untuk memikirkan topik secara mendalam; dan (3) pengetahuan dasar apa yang mungkin dimiliki atau tidak dimiliki para siswa. Hal ini menjadi dasar guru dalam mengarahkan pembelajaran yang lebih efisien. Para observer menanggapi rencana pembelajaran yang telah disampaikan oleh guru model dan memberikan masukan berupa waktu penyampaian sekitar 5-10 menit, kemudian siswa dipersilahkan mengeksplorasi materi yang telah dipaparkan. 


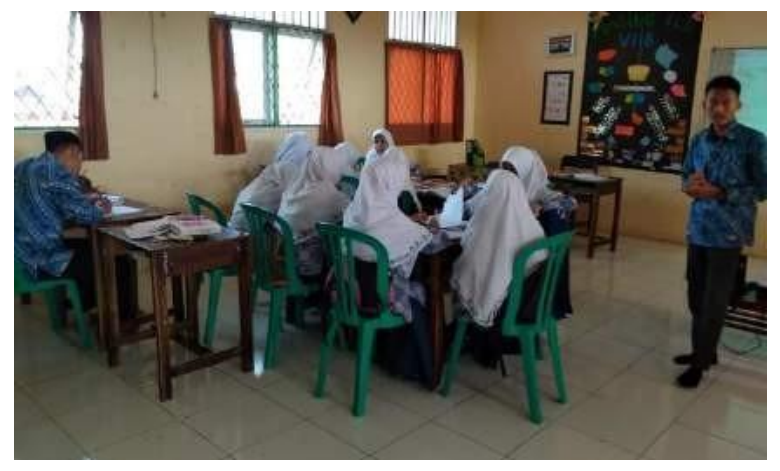

Gambar 4: Pelaksanaan Do (Pelaksanaan) Mata Pelajaran IPS

Tahap lesson study berikutnya adalah pelaksanaan (do) pembelajaran. Menurut I Wayan Santyasa (2009: 7) pada tahap pelaksanaan lesson study bertujuan untuk mengimplementasikan rancangan pembelajaran. Hal ini sesuai dengan pendapat Daryanto dan Muljo (2012: 44), pelaksanaan (do) pembelajaran untuk menerapkan rancangan pembelajaran yang telah dirumuskan dalam perencanaan.

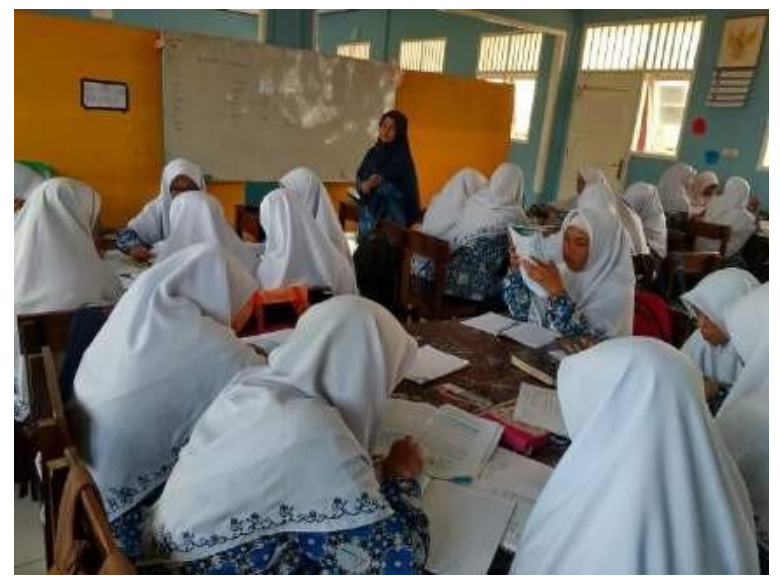

Gambar 5: Pelaksanaan Do (Pelaksanaan) Mata Pelajaran IPA

Pada tahap ini, guru model berperan sebagai pelaksana lesson study dan guru yang lain sebagai pengamat pembelajaran. Dosen pengabdi dan kepala sekolah juga terlibat dalam melakukan pengamatan pembelajaran. Hal tersebut sesuai dengan pernyataan Hadiyanto Sahputra (2009), pada tahap yang kedua, terdapat dua kegiatan utama yaitu: (1) kegiatan pelaksanaan pembelajaran yang dilakukan oleh guru model untuk mempraktikkan RPP yang telah disusun bersama, dan (2) kegiatan pengamatan atau observasi yang dilakukan oleh anggota atau komunitas lesson study yang lainnya yakni guru, kepala sekolah, dan tim pengabdi yang bertindak sebagai pengamat/observer.

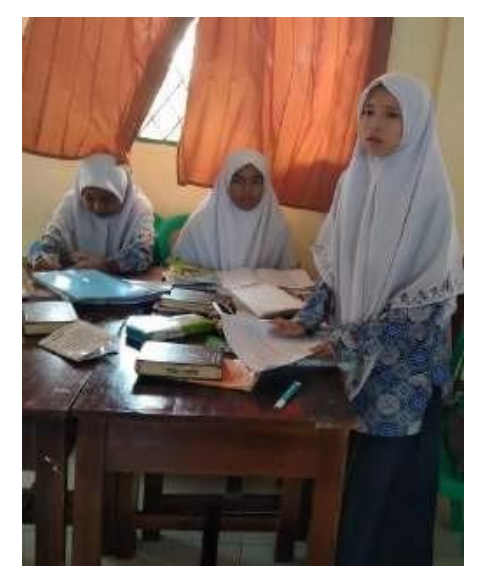

Gambar 4: Pelaksanaan Do (siswa bertanya) Mata Pelajaran IPS

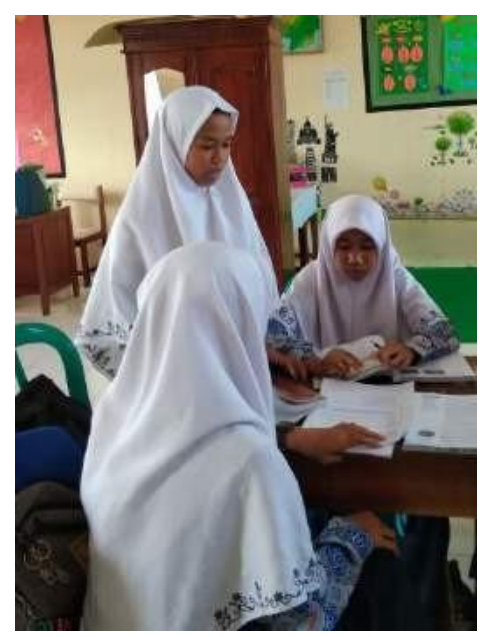

Gambar 5: Pelaksanaan Do (siswa menjawab) Mata Pelajaran IPS 


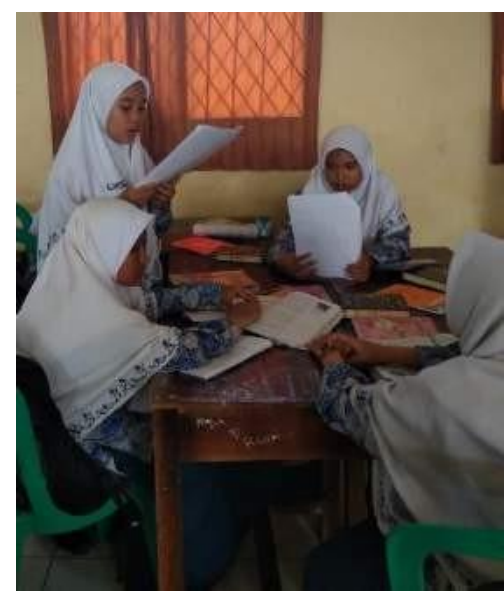

Gambar 6: Pelaksanaan Do (siswa menanggapi pernyataan) Mata Pelajaran IPS

Pada pelaksanaan lesson study, guru model memperhatikan proses pembelajaran. Guru model berusaha mengubah cara mengajarnya dalam menyampaikan ilmu yaitu, dari yang bersifat pengajaran kelas (klasikal) menjadi suatu pembelajaran yang sifatnya mengeksplorasi. Pembelajaran yang mengeksplorasi memberikan kesempatan siswa untuk menggali, berpikir, dan memecahkan masalah. Pengamat tidak ada yang mengajari siswa ketika berlangsungnya lesson study pembelajaran IPA dan IPS. Mereka mencatat hasil temuannya sesuai yang ada di lembar observasi.

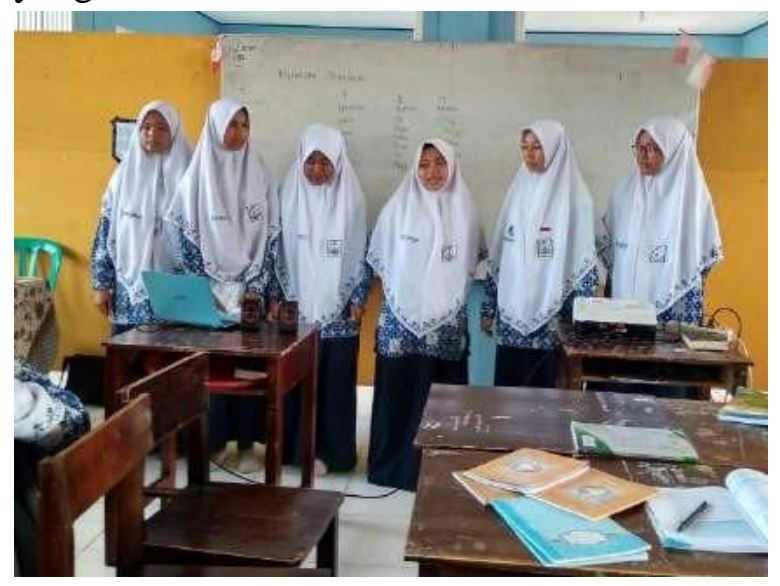

Gambar 7: Pelaksanaan Do (siswa memaparkan konsep) Mata Pelajaran IPA

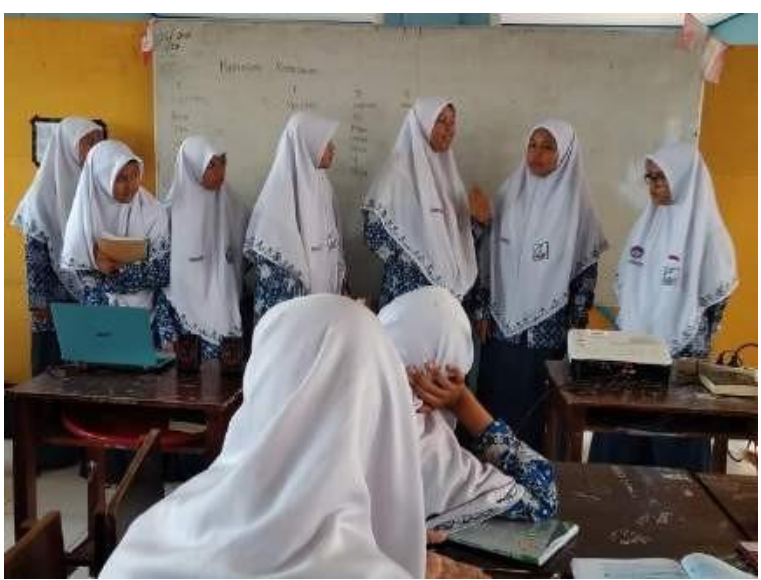

Gambar 8: Pelaksanaan Do (siswa menjawab pertanyaan) Mata Pelajaran IPA

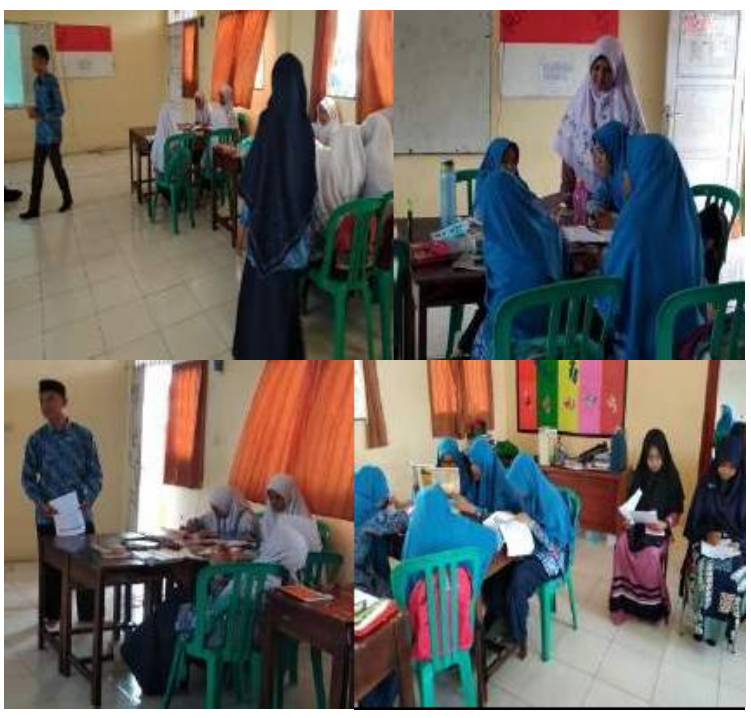

Gambar 9 : Observer Mengamati Siswa

Guru model sudah menerapkan prinsip-prisip pembelajaran seperti media bagus, sudah menarik perhatian siswa pada pembelajaran, memotivasi siswa dengan gurauan yang sesuai materi, dapat mengaktifkan siswa, mendekati siswa ada yang tidak memperhatikan, dekat dengan siswa, pendapat anak dihargai dengan tepuk tangan, suka mengulang kata untuk penekanan. 
Tahap terakhir dari lesson study adalah refleksi. Setelah pelaksanaan pembelajaran dilakukan diskusi antara guru dan pengamat yang dipandu oleh tim pengabdian masyarakat ini. Pada tahap refleksi ini ditemukan kelebihan dan kekurangan pelaksanaan pembelajaran (I Wayan Santyasa, 2009). Kelebihan dan kekurangan pembelajaran dapat menjadi pelajaran bersama demi pembelajaran berikutnya yang lebih baik.

Guru model mengawali diskusi dengan menyampaikan kesan dalam melaksanakan pembelajaran, kemudian pengamat diminta menyampaikan komentar dari pembelajaran terutama mengenai aktivitas siswa. observer diberi kesempatan untuk memberikan masukan-masukan proses pembelajaran. Kritik dan saran disampaikan secara bijak berdasarkan bukti kenyataan demi perbaikan pembelajaran, dan guru model menerima masukan dari pengamat demi pembelajaran berikutnya.

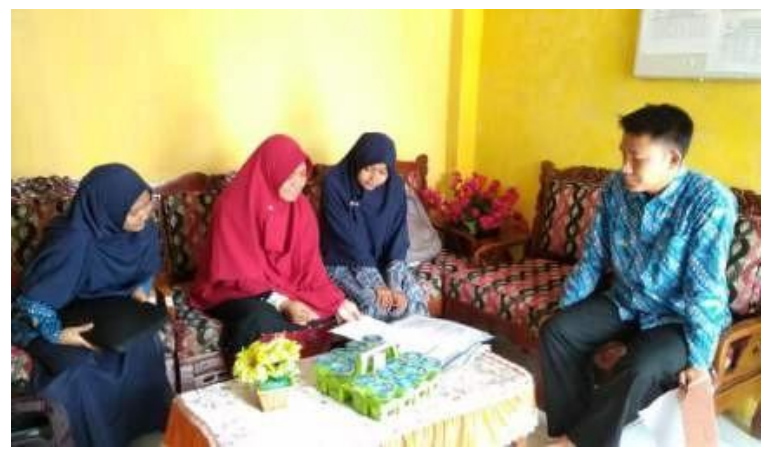

Gambar 10: Pelaksanaan See (Refleksi) Mata Pelajaran IPA

Masukan yang positif digunakan untuk merancang kembali pembelajaran yang lebih baik. hal ini sesuai dengan pernyataan Prayekti dan Rasyimah (2012), dari hasil refleksi dapat diperoleh sejumlah pengetahuan baru atau keputusan-keputusan penting guna perbaikan dan peningkatan proses pembelajaran.

Berdasarkan hasil observasi dan dokumentasi notulen refleksi, bahwa guru model mengucapkan terimakasih telah mengikuti dari awal sampai akhir, mengucapkan rasa syukur kegiatan dapat berjalan lancar, mengucapkan terimakasih kepada tim yang membantu dan telah mengikuti do dan see. Kemudian pengamat menyampaikan tanggapannya sudah baik, tidak memojokkan guru model, kritik dan saran yang disampaikan membangun, sudah disertai bukti nyata dalam pembelajara

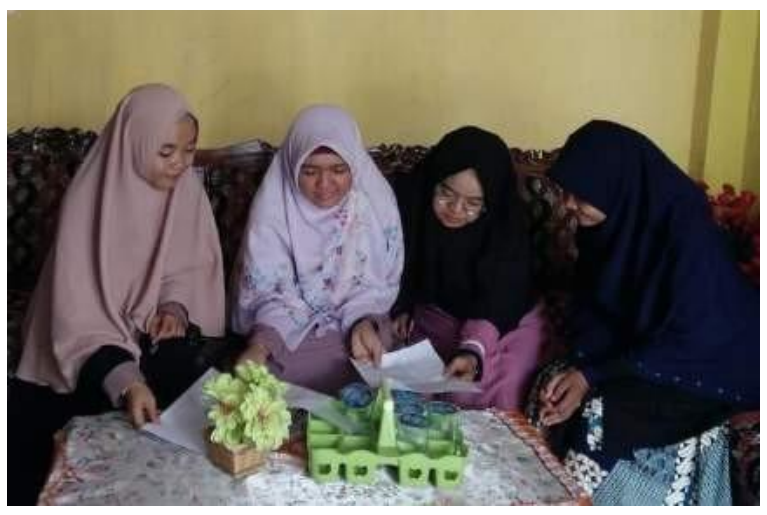

\section{Gambar 11: Pelaksanaan See (Refleksi) Mata Pelajaran IPS}

\section{Dampak}

Pengabdian masyarakat ini menunjukkan adanya perbedaan kualitas pembelajaran sebelum dan sesudah dilaksanakannya Lesson Study pada para siswa SMPIT Generasi Rabbani Kota Bengkulu.

\section{Bagi para siswa SMPIT Generasi} Rabbani, lesson study sangat membantu proses pembelajaran mereka. Siswa memperhatikan pembelajaran, sebagian 
besar siswa sudah memahami dan tujuan pembelajaran dapat tercapai dilihat dari mengerjakan LKS, hasil presentasi siswa dan siswa lebih banyak yang aktif dari pembelajaran biasanya.

Hal ini sesuai dengan pendapat Daryanto dan Muljo (2012), dalam proses pembelajaran, guru dapat menggali dan mengembangkan aktifitas pembelajaran yang berpusat pada siswa. Menurut Abdul Gafur (2012), aktifitas siswa meliputi aktifitas mental (memikirkan jawaban, merenungkan, membayangkan, merasakan) dan aktifitas fisik (melakukan latihan, menjawab pertanyaan, merangsang, menulis, mengerjakan tugas, dsb). Pada proses pembelajaran siswa harus aktif belajar dan guru hanya membimbing dan mengarahkan. Pendekatan pembelajaran yang mampu melibatkan siswa secara langsung akan menghasilkan pembelajaran yang lebih efektif sehingga dapat mencapai tujuan pembelajaran (Daryanto dan Muljo, 2012).

\section{Penutup}

Berdasarkan hasil pengabdian masyarakat berupa implementasi Lesson Study pada Mata Pelajaran IPA dan IPS di SMPIT Generasi Rabbani Kota Bengkulu dapat diambil kesimpulan sebagai berikut : Kegiatan lesson study dalam pembelajaran memberikan manfaat bagi guru, siswa maupun sekolah. Hal ini dapat diketahui berdasarkan hasil wawancara dan hasil observasi, yaitu

1) Memberikan pengalaman bagi guru model untuk menjadi guru yang lebih profesional
2) Terdapat perbaikan perencanaan, pelaksanaan, penilaian.

3) Lesson study memberikan wawasan bagaimana pembelajaran yang baik atau tidak baik, contohnya ketika diskusi tidak perlu semua kelompok tampil presentasi agar tidak membuang waktu

4) Metode bertambah karena biasanya hanya ceramah

5) Guru model dapat meningkatkan penggunaan media karena jarang menggunakan LCD

6) Siswa lebih memperhatikan pembelajaran dan aktif.

Beberapa saran yang dapat dikemukakan adalah:

a. Guru Mata Pelajaran IPA dan IPS merutinkan pelaksanaan Lesson Study

b. Adanya pemantauan kepala sekolah untuk terus mendorong guru melaksanakan kegiatan lesson study.

c. Sekolah menindaklanjuti untuk melengkapi fasilitas sekolah agar pembelajaran lebih baik.

\section{Daftar Pustaka}

1. Aris Shoimin. 2014. 68 Model Pembelajaran Inovatif Dalam Kurikulum 2013. Yogyakarta: Ar-Ruzz Media.

2. Rusman. 2011. Model-model pembelajarn mengembangkan profesionalisme Guru. Jakarta : PT Raja Grafindo Persada

3. Yan Vita. 2014. Metode-metode pembelajaran PAI dan Budi Pekerti 
Pendekatan Scientific. Semarang: Rasail Media Group

4. Moh. Roqib dan Nurfuadi. 2009. "Kepribadian Guru: Upaya Mengembangkan Kepribadian Guru yang Sehat di Masa Depan", Jogjakarta: Grafindo Litera Media.

5. Peraturan Perundangan Nomor 19 Tahun 2005 Tentang Standar Nasional Pendidikan

6. Daryanto, dan Mulyo Rahardjo. 2012. Model Pembelajaran Inovatif. Yogyakarta: Gava Media.

7. Abdul Gafur. 2012. Desain Pembelajaran : Konsep, Model, dan Aplikasinya dalam Perencanaan Pelaksanaan Pembelajaran.

Yogyakarta : Ombak.

8. Supardi. 2011. Penelitian Tindakan Kelas (Classroom Action Research) Beserta Sistematika Proposal dan Laporannya. Jakarta : Bumi Aksara.

9. Nurbaity, Sondang, dan Wahyu Rochadi Utami. 2010. Meningkatkan Aktivitas Belajar Siswa Dalam IPA Terpadu Menggunakan Penilaian Portofolio Melalui Lesson Study di SMP Sekolah Alam dan Sains Aljannah Jakarta. Jurnal Pendidikan dan Kebudayaan, Vol. 16, Nomor 6, Nopember 2010.

10. Santyasa, I Wayan. 2009. Metode Penelitian Pengembangan dan Teori Pengembangan Modul. Makalah Disajikan dalam Pelatihan Bagi Para Guru TK, SD, SMP, SMA, dan SMK Tanggal 12-14 Januari 2009, Di Kecamatan Nusa Penida kabupaten Klungkung

11. Prayekti dan Rasyimah, 2012. Lesson Study Untuk Meningkatkan Hasil
Belajar Ilmu Pengetahuan Alam Bagi Siswa Sekolah Dasar. Jakarta: Jurnal Pendidikan dan Kebudayaan, Vol. 18, Nomor 1, Maret 2012

12. Suparno, N \& Tamtomo H. 2016. Ilmu Pengetahuan Sosial (IPS) Terpadu untuk SMP Kelas VII. Jakarta: Erlangga.

13. Setiawan. I, Suciati, Dedi, \& Muslich A. 2016. Ilmu Pengetahuan Sosial SMP Kelas VII. Jakarta: Pusat Kurikulum dan Perbukuan Balitbang Kemdikbud.

14. Setiawan. I, Suciati, Dedi, \& Muslich A. 2017. Buku Guru Ilmu Pengetahuan Sosial SMP Kelas VII. Jakarta: Pusat Kurikulum dan Perbukuan Balitbang Kemdikbud.

15. Undang-Undang No. 14 Tahun 2005 Tentang Guru dan Dosen. 